\title{
UMUR ORANG DENGAN HIV AIDS (ODHA) BERHUBUNGAN DENGAN TINDAKAN PENCEGAHAN PENULARAN HIV
}

\author{
Yowel Kambu $^{1 *}$, Agung Waluyo ${ }^{2}$, Kuntarti $^{2}$ \\ 1. Poltekkes Kementerian Kesehatan Sorong, Papua Barat 98417, Indonesia \\ 2. Fakultas Ilmu Keperawatan Universitas Indonesia, Depok 16424, Indonesia \\ *E-mail: yowel76@yahoo.com
}

\begin{abstract}
Abstrak
HIV/AIDS mengancam eksistensi manusia, sehingga perlu dilakukan tindakan pencegahan penularannya. Tujuan penelitian adalah mengidentifikasi faktor-faktor yang memengaruhi tindakan pencegahan penularan HIV oleh ODHA. Desain penelitian adalah deskriptif analitik cross sectional. Teknik pengambilan sampel adalah consecutive sampling. Penelitian dilakukan pada dua rumah sakit Pemerintah dan satu Klinik Yayasan Sosial di Sorong Papua Barat. Jumlah responden yang diperoleh 75 orang. Hasil penelitian menunjukkan bahwa faktor yang berhubungan dengan tindakan pencegahan penularan HIV adalah umur $(\mathrm{p}=0,040 ; \alpha=0,05)$. Pada analisis regresi logistik ganda diketahui bahwa umur merupakan faktor yang paling memengaruhi tindakan pencegahan penularan HIV ( $\mathrm{p}=0,031 ; \alpha=0,05 ; 95 \%$ CI: 1,169 26,423). Umur muda berisiko menularkan HIV karena cenderung melakukan seks tidak aman. Perawat dalam memberikan asuhan keperawatan harus berfokus pada intervensi konseling bagaimana menghindari perilaku seks tidak aman.
\end{abstract}

Kata kunci: $O D H A$, pencegahan, penularan $H I V$

\begin{abstract}
Age People with HIV AIDS (PLWHA) Precautions in Connection with HIV Infection. HIV/AIDS has threaten the human existence, so it necessary to actions to prevent the HIV transmissions. The aim of this study was to determine the factors that influence the act of HIV transmission prevention by PLWHA. The study design was cross sectional analytic descriptive approach. The sampling technique is consecutive. The study was conducted at two government hospitals and one private clinic in Sorong. The number of respondents is 75 people. The results showed that factors correlated to the prevention of HIV transmission is age $(p=0.040 ; \alpha=0.05)$. In multiple logistic regression analysis it is known that age is a factor that most influences the actions of prevention of HIV transmission $(p=0.031 ; \alpha=0.05 ; 95 \%$ CI: 1.16926.423). The young age due to become infected with HIV were more likely to perform unsafe sex. The provision of nursing care shlould be focused on the interventions counseling how to avoid unsafe sex.
\end{abstract}

Keywords: HIV transmission, PLWHA, prevention

\section{Pendahuluan}

HIV/AIDS adalah penyakit defisiensi imun sekunder yang paling umum di dunia dan sekarang menjadi masalah epidemik dunia yang serius (Ignatavicius \& Workman, 2010). Menurut UNAIDS WHO (2009), total orang hidup dengan positif HIV di dunia adalah 33,4 juta. Di Indonesia, hingga Desember 2010 jumlah kasus AIDS baru yang dilaporkan adalah 1.405 kasus (P2PL, 2011).
Data DinKes Provinsi Papua Barat per 30 Juni 2009, total kasus HIV/AIDS sebanyak 1.589. KPA Papua Barat menyebutkan prevalensi HIV/AIDS pada populasi umum telah mencapai lebih dari 1\% (Papua, 2010). Kasus HIV/AIDS di kota Sorong cukup tinggi. Data tercatat menunjukkan dan terdapat 742 kasus HIV/AIDS dengan 175 orang meninggal dunia sejak September 2009 (Margono, 2010). 


\section{Metode}

Metode penelitian ini adalah deskriptif analitik dengan desain cross sectional melalui pendekatan survei dengan menggunakan instrumen berupa kuesioner untuk mengetahui korelasi antara faktor-faktor yang memengaruhi tindakan tindakan pencegahan penularan HIV. Peneliti melakukan observasi atau pengukuran variabel pada satu saat tertentu (Sastroasmoro \& Ismael, 2010). Teknik pengambilan sampel dalam penelitian ini adalah Non Probability Sampling: Consecutive Sampling.

\section{Hasil}

Hasil penelitian didapatkan 75 responden yang terlibat dalam penelitian ini. Hasil penelitian menunjukkan tidak terdapat perbedaan yang signifikan antara jenis kelamin perempuan dan laki-laki $(49,3 \%$ vs 50,7\%). Berdasarkan umur dan tingkat pendidikan dan status perkawinan responden terbesar adalah umur muda $(69,3 \%)$, pendidikan rendah $(82,5 \%)$, dan kawin $(61,3 \%)$. Selain itu, responden terbesar pada penelitian ini terdapat pada kategori yang bekerja $(61,3 \%)$ (tabel 1). Pada tingkat pengetahuan, sebagian besar responden termasuk dalam kategori baik $(62,7 \%)$. Sikap responden tentang pencegahan penularan HIV sebagian besar termasuk dalam kategori baik $(96,0 \%)$. Responden pada penelitian ini yang teridentifikasi positif HIV/AIDS sebagian besar termasuk kategori lama $(72,0 \%)$ dan sudah mendapat ART (66,7\%). Pada diagram 1 memperlihatkan bahwa sebagian besar responden $(73,3 \%)$ termasuk dalam kelompok cukup dalam melakukan tindakan pencegahan penularan HIV. Pada tabel 2 terlihat bahwa distribusi responden lebih besar pada kelompok

Tabel 1. Karakteristik Responden berdasarkan Jenis Kelamin, Umur, Tingkat Pendidikan, Status Perkawinan, Pekerjaan, Pengetahuan, Sikap, Lama Menderita HIV/AIDS dan Status Mendapat ART

\begin{tabular}{|c|c|c|}
\hline Kategori & Jumlah & $\%$ \\
\hline $\begin{array}{l}\text { Jenis kelamin } \\
\text { - Perempuan } \\
\text { - Laki-laki }\end{array}$ & $\begin{array}{l}37 \\
38\end{array}$ & $\begin{array}{l}49,3 \\
50,7\end{array}$ \\
\hline $\begin{array}{l}\text { Status perkawinan } \\
\text { - Kawin } \\
\text { - Tidak Kawin }\end{array}$ & $\begin{array}{l}46 \\
29\end{array}$ & $\begin{array}{l}61,3 \\
38,7\end{array}$ \\
\hline $\begin{array}{l}\text { Pekerjaan } \\
\text { - Tidak bekerja } \\
\text { - Bekerja }\end{array}$ & $\begin{array}{l}29 \\
46\end{array}$ & $\begin{array}{l}38,7 \\
61,3\end{array}$ \\
\hline $\begin{array}{l}\text { Pengetahuan } \\
\text { - Baik } \\
\text { - Kurang }\end{array}$ & $\begin{array}{l}47 \\
28\end{array}$ & $\begin{array}{l}62,7 \\
37,3\end{array}$ \\
\hline $\begin{array}{l}\text { Sikap } \\
\text { - Baik } \\
\text { - Kurang }\end{array}$ & $\begin{array}{c}72 \\
3\end{array}$ & $\begin{array}{c}96,0 \\
4,0\end{array}$ \\
\hline $\begin{array}{l}\text { Lama menderita HIV/AIDS } \\
\text { - Lama (> } 6 \text { bulan }) \\
\text { - Lama ( } \leq 6 \text { bulan })\end{array}$ & $\begin{array}{l}54 \\
21\end{array}$ & $\begin{array}{l}72,0 \\
28,0\end{array}$ \\
\hline $\begin{array}{l}\text { Status mendapat ART } \\
\text { - Sudah } \\
\text { - Belum }\end{array}$ & $\begin{array}{l}50 \\
25\end{array}$ & $\begin{array}{l}66,7 \\
33,3\end{array}$ \\
\hline
\end{tabular}


Tabel 2. Analisis Hubungan antara Faktor-faktor yang Memengaruhi dan Tindakan Pencegahan Penularan HIV

\begin{tabular}{|c|c|c|c|c|c|c|c|c|}
\hline \multirow{3}{*}{ Variabel } & \multicolumn{4}{|c|}{$\begin{array}{c}\text { Tindakan Pencegahan Penularan } \\
\text { HIV }\end{array}$} & \multirow{2}{*}{\multicolumn{2}{|c|}{ Total }} & \multirow{3}{*}{$\begin{array}{c}\operatorname{Exp} B \\
(\text { OR) }\end{array}$} & \multirow[t]{3}{*}{$\mathbf{P}$} \\
\hline & \multicolumn{2}{|c|}{ Cukup } & \multicolumn{2}{|c|}{ Kurang } & & & & \\
\hline & $\mathbf{N}$ & $\%$ & $\mathbf{N}$ & $\%$ & $\mathbf{N}$ & $\%$ & & \\
\hline \multicolumn{9}{|l|}{ Pengetahuan } \\
\hline - Baik & 38 & 80,0 & 9 & 19,1 & 47 & 100 & \multirow{2}{*}{2,732} & \multirow{2}{*}{0,102} \\
\hline - Kurang & 17 & 60,7 & 11 & 39,3 & 28 & 100 & & \\
\hline \multicolumn{9}{|l|}{ Sikap } \\
\hline - Baik & 52 & 72,2 & 20 & 27,8 & 72 & 100 & \multirow{2}{*}{$\mathbf{0 , 7 2 2}$} & \multirow{2}{*}{$\mathbf{0 , 5 6 0}$} \\
\hline - Kurang & 3 & 100,0 & 0 & 0,0 & 3 & 100 & & \\
\hline \multicolumn{9}{|l|}{ Umur } \\
\hline - Tua (36-65 Tahun) & 21 & 91,3 & 2 & 8,7 & 23 & 100 & \multirow{2}{*}{5,559} & \multirow{2}{*}{$0,040 *$} \\
\hline - Muda (12-35 Tahun) & 34 & 65,4 & 18 & 34,6 & 52 & 100 & & \\
\hline \multicolumn{9}{|l|}{ Jenis Kelamin } \\
\hline - Perempuan & 28 & 75,5 & 9 & 24,3 & 37 & 100 & \multirow{2}{*}{1,267} & \multirow{2}{*}{0,848} \\
\hline - Laki-laki & 27 & 71,1 & 11 & 28,9 & 38 & 100 & & \\
\hline \multicolumn{9}{|l|}{ Tingkat Pendidikan } \\
\hline - Tinggi (PT) & 12 & 92,3 & 1 & 7,7 & 13 & 100 & \multirow{2}{*}{5,302} & \multirow{2}{*}{0,165} \\
\hline - Rendah (SMU, SMP, SD) & 43 & 69,4 & 19 & 30,6 & 62 & 100 & & \\
\hline \multicolumn{9}{|l|}{ Status Perkawinan } \\
\hline - Kawin & 37 & 80,4 & 9 & 19,6 & 46 & 100 & \multirow{3}{*}{2,512} & \multirow{3}{*}{$\mathbf{0 , 1 3 8}$} \\
\hline - Tidak & 18 & 61,2 & 11 & 37,9 & 29 & 100 & & \\
\hline \multicolumn{7}{|l|}{ Pekerjaan } & & \\
\hline - Tidak Bekerja & 21 & 72,4 & 8 & 27,6 & 29 & 100 & \multirow{3}{*}{0,926} & \multirow{2}{*}{1,000} \\
\hline - Kerja & 34 & 73,9 & 12 & 26,1 & 46 & 100 & & \\
\hline \multicolumn{8}{|l|}{ Lama Menderita HIV/AIDS } & \\
\hline - Baru ( $\leq 6$ bulan) & 14 & 66,7 & 7 & 33,3 & 21 & 100 & \multirow[t]{2}{*}{1,577} & 0,601 \\
\hline - Lama (>6 bulan) & 41 & 75,9 & 13 & 24,1 & 44 & 100 & & \\
\hline Status Mendapat ART & & & & & & & & \\
\hline - Sudah & 39 & 78,0 & 11 & 22,0 & 50 & 100 & 1.994 & 0310 \\
\hline - Belum & 16 & 64,1 & 9 & 36,0 & 25 & 100 & 1,994 & 0,310 \\
\hline
\end{tabular}

Keterangan: *Bermakna pada $\mathrm{p} \leq 0,05$

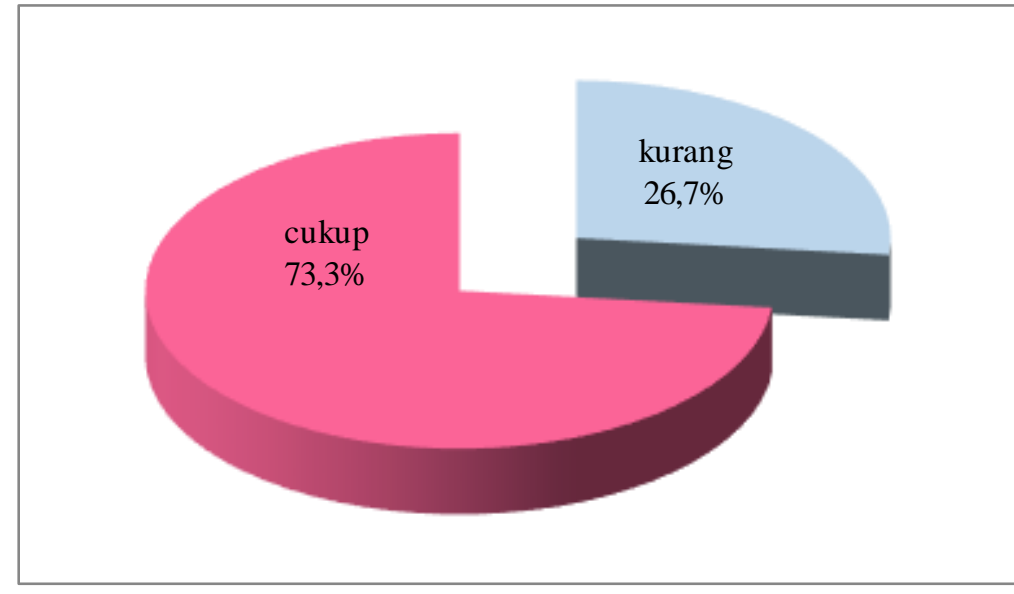

Gambar 1 Responden Berdasarkan Kategori Tindakan Pencegahan Penularan HIV 
tindakan pencegahan penularan HIV termasuk kategori cukup dari segi pengetahuan, sikap, umur, jenis kelamin, tingkat pendidikan, status perkawinan, bekerja, lamanya menjadi ODHA, dan sudah mendapat ART. Namun demikian, masih ada beberapa ODHA yang termasuk dalam kategori kurang.

Uji statistik menggu-nakan Chi square test menunjukkan tidak ada-nya hubungan yang signifikan antara pengeta-huan $(p=0,102 ; \alpha=$ $0,05 ; \mathrm{OR}=2,732)$, jenis kelamin $(\mathrm{p}=0,840 ; \alpha=$ $0,05 ;$ OR $=1,267)$, status perkawinan $(\mathrm{p}=$ $0,138 ; \alpha=0,05 ; \mathrm{OR}=2,512)$, pekerjaan $(\mathrm{p}=$ $1,000 ; \alpha=0,05 ; \mathrm{OR}=0,926)$, lama menderita HIV/AIDS $(p=0,601 ; \alpha=0,05 ; \mathrm{OR}=1,139)$, dan status mendapat ART ( $\mathrm{p}=0,310 ; \alpha=0,05$; $\mathrm{OR}=1,944)$ dengan tindakan pencegahan penularan HIV. Hanya variabel umur $(\mathrm{p}=$ $0,040 ; \alpha=0,05 ; \quad O R=5,559)$ yang menunjukkan adanya hubungan yang signifikan $(p \leq 0,05)$ dengan tindakan pencegahan penularan HIV. Selain itu, dilakukan juga uji alternatif menggunakan Fisher exact test pada variabel sikap dan pendidikan yang menun- jukkan tidak adanya hubungan yang signifikan antara variabel sikap $(\mathrm{p}=0,560 ; \alpha=0,05 ; \mathrm{OR}=$ $\mathrm{O}, 722)$ dan pendidikan ( $\mathrm{p}=0,165 ; \alpha=0,05$; $\mathrm{OR}=5,302)$ dengan tindakan pencegahan penularan HIV.

Pada analisis multivariat terlihat bahwa sebagian besar variabel independen yang diuji korelasi hanya variabel pengetahuan, umur, tingkat pendidikan dan status perkawinan yang termasuk variabel kandidat $(\mathrm{p} \leq 0,250)$.

Pada Tabel 3 nampak model pertama dari 4 variabel kandidat, tidak ada variabel kandidat yang signifikan. Walaupun demikian, tetap dilakukan pemodelan selanjutnya. Variabel dengan nilai $\mathrm{p}$ tertinggi dikeluarkan dari model satu per satu sampai didapatkan model parsimony yang memenuhi signifikansi model dan signifikansi parsial. Dalam penelitian ini tidak terdapat variabel confounding sehingga peneliti tidak menghitung perubahan OR (Exp B) variabel kandidat lainnya setelah salah satu variabel kandidat dikeluarkan dari model. Variabel yang tidak memenuhi signifikansi

Tabel 3. Hasil Analisis Regresi Logistik Ganda Faktor-faktor yang Memengaruhi Tindakan Pencegahan Penularan HIV

\begin{tabular}{|c|c|c|c|c|}
\hline \multirow[t]{2}{*}{$\begin{array}{ll}\text { Variabel } \\
\end{array}$} & \multirow[t]{2}{*}{$\mathbf{p}$} & \multirow[t]{2}{*}{$\operatorname{Exp} B(\mathrm{OR})$} & \multicolumn{2}{|c|}{$95 \%$ CI for $\operatorname{Exp}(B)$} \\
\hline & & & Lower & Upper \\
\hline \multicolumn{5}{|l|}{ Model Pertama } \\
\hline - Pengetahuan & 0,116 & 2.557 & .792 & 8.253 \\
\hline - Umur & 0,056 & 4.772 & .960 & 23.727 \\
\hline - tingkat pendidikan & $0,240 *$ & 3.734 & 416 & 33.534 \\
\hline - status perkawinan & 0,102 & 2.626 & .826 & 8.346 \\
\hline Constant & 0,001 & & & \\
\hline \multicolumn{5}{|l|}{ Model Kedua } \\
\hline - pengetahuan & 0,058 & 3.031 & 964 & 9.536 \\
\hline - umur & 0,054 & 4.789 & .973 & 23.580 \\
\hline - status perkawinan & $0,084 *$ & 2.744 & .873 & 8.628 \\
\hline Constant & 0,000 & & & \\
\hline \multicolumn{5}{|l|}{ Model Ketiga } \\
\hline - pengetahuan & $0,086 *$ & 2.598 & .873 & 7.728 \\
\hline - umur & $\mathbf{0 , 0 3 8 * *}$ & 5.330 & 1.101 & 25.805 \\
\hline Constant & 0,001 & & & \\
\hline \multicolumn{5}{|l|}{ Model Keempat } \\
\hline - Umur & $0,031^{* *}$ & 5.559 & 1.169 & 26.423 \\
\hline Constant & $\mathbf{0 , 0 0 1}$ & & & \\
\hline
\end{tabular}

Keterangan: * Variabel yang akan dikeluarkan pada pemodelan secara

Bertahap Karena nilai $\mathrm{p}>0,05$, dimulai dari nilai $p$ yang tertinggi.

$* *$ Bermakna pada $\mathrm{p} \leq 0,05$. 
parsial langsung dikeluarkan dari pemodelan. Setelah melalui empat kali tahapan seleksi variabel kandidat, sekarang tarlihat bahwa variabel yang signifikan $(\mathrm{p} \leq 0,05)$ yaitu umur memiliki nilai $\mathrm{p}=0,031$. Dengan demikian dapat disimpulkan bahwa tindakan pencegahan penularan HIV oleh ODHA di Sorong dapat diprediksi oleh vari-abel umur. Berikut interpretasi Odd Ratio (OR) berdasarkan nilai Exp (B): ODHA umur muda berisiko 5,5 kali untuk kurang dalam melakukan tindakan pencegahan penularan HIV dibandingkan umur tua tanpa dikontrol oleh variabel lain.

\section{Pembahasan}

Hubungan Umur dengan Tindakan Pencegahan Penularan HIV. Pada penelitian ini, didapatkan perbedaan proporsi yang bermakna antara ODHA umur muda dan tua. Data ini dapat menjelaskan bahwa infeksi HIV ternyata lebih banyak terjadi pada umur muda ketimbang umur tua. Hal ini disebabkan karena umur muda lebih mungkin banyak melakukan perilaku seks tidak aman yang berisiko terhadap penularan HIV.

Hasil penelitian ini sejalan dengan Penelitian oleh USAIDS-FHI bekerjasama dengan Lembaga Penelitian Universitas Cenderawasih menggunakan metode Etnografi dengan pendekatan Rapid Anthropological Assesment Procedures tentang Program seksualitas Orang Papua (2002, dalam Dumatubun, 2003) menjelaskan adanya hubungan antara aktivitas seksual dalam kebudayaan suku bangsa Marind-Anim dengan kasus epidemi AIDS di Merauke. Terdapat berbagai ritual seks bebas di kalangan suku bangsa Marind-Anim, khususnya pada umur muda. Dapat disimpulkan bahwa ODHA umur muda lebih berisiko berperilaku seksual tidak aman sehingga kurang dalam melakukan tindakan pencegahan penularan HIV dibandingkan dengan umur tua. Namun, dalam beberapa kasus umur tua dapat juga berperilaku seks berisiko.
Hubungan Jenis Kelamin dengan Tindakan Pencegahan Penularan HIV. Deskripsi statistik penelitian ini menjelaskan bahwa distribusi penularan HIV tidak terletak pada perbedaan jenis kelamin. Penelitian Irmanigrum, et al., (2007) menemukan bahwa frekuensi kontak seksual berganti-ganti pasangan di Papua menunjukkan perbedaan yang signifikan antara laki-laki dan perempuan, yaitu proporsi terbesar dimana pada laki-laki sebesar $28 \%$, sementara proporsi terkecil yaitu pada perempuan sebesar $12 \%$. Tinggi-nya prevalensi kasus HIV/AIDS pada laki-laki lebih dikarenakan oleh perilaku seksual berisiko yang lebih rentan dilakukan laki-laki dibandingkan perempuan.

Pada analisis statistik menunjukkan tidak adanya hubungan antara jenis kelamin dengan tindakan pencegahan penularan HIV. Walaupun tidak berhubungan dan distribusi tindakan pencegahan penularan HIV antara lakilaki dan perempuan dalam kategori cukup, namun penularan HIV di Papua khususnya di Sorong tetap saja terjadi dan terus menunjukkan peningkatan bermakna dari tahun ke tahun. Hal ini terjadi karena infeksi HIV sebagian besar terjadi melalui kontak seksual (Dachlia, 2000).

\section{Hubungan Tingkat Pendidikan dengan Tindakan Pencegahan Penularan HIV.} Penelitian ini menunjukkan tidak adanya hubungan yang signifikan antara tingkat pendidikan dengan tindakan pencegahan penularan HIV ( $p=0,165)$. Walaupun tidak berhubungan, tingkat pendidikan memiliki nilai derajat hubungan yang tinggi $(\mathrm{OR}=5,302)$ yang mengindikasikan ODHA dengan pendidikan rendah berisiko 5,3 kali untuk kurang dalam melakukan tindakan pencegahan penularan HIV. Seseorang yang berpendidikan memiliki penyerapan dan pemahaman terhadap informasi lebih baik, khususnya informasi kesehatan tentang pencegahan penularan HIV. Pendidikan adalah salah satu senjata yang paling 
ampuh untuk mencegah penularan HIV (AlSerouri, Anaam, Al-Iryani, Al Deram, dan Ramaroson,2010).

Hasil penelitian lain yang tidak sejalan yaitu sebuah survei terkini oleh majalah People di Amerika yang menemukan $96 \%$ siswa pada tingkat pendidikan menengah atas dan $99 \%$ mahasiswa perguruan tinggi tahu bahwa HIV menular melalui populasi heteroseksual, tetapi mayoritas pelajar ini menyatakan bahwa mereka tetap melakukan hubungan seks tidak aman dan 26\% dewasa muda Amerika melakukan praktik anal seks (Stine, 2011). Walaupun tidak menggambarkan populasi ODHA, namun penelitian ini menunjukkan juga bahwa tingkat pendidikan yang lebih tinggi tidak menjamin seseorang dapat melakukan tindakan pencegahan penularan HIV dengan baik (Stine, 2011).

\section{Hubungan Status Perkawinan dengan} Tindakan Pencegahan Penularan HIV. Tingginya angka kasus ODHA yang telah kawin dapat disebabkan karena penularan HIV melalui kontak seksual dari pasangannya (suami/istri). Lebih berisiko penularan terjadi dari pasangan laki-laki ke pasangan perempuan dari pada sebaliknya.

Beberapa studi lain yang berbeda dengan hasil penelitian ini memperlihatkan bahwa status tidak kawin berhubungan erat dengan perilaku seksual berisiko (Dachlia, 2000). Studi Havanon (1993, dalam Dachlia, 2000) antara lain menyebutkan bahwa responden dengan status tidak kawin lebih banyak yang terlibat dalam hubungan seksual dengan PSK dibandingkan kelompok yang sudah kawin (56\% vs 44\%).

Hubungan Pekerjaan dengan Tindakan Pencegahan Penularan HIV. Penelitian ini menunjukkan bahwa perban-dingan antara ODHA bekerja dan tidak be-kerja adalah 2 : 1. Analisis statistik penelitian ini menunjukkan tidak adanya hubungan antara pekerjaan dengan tindakan pencegahan penularan HIV.
Walaupun tidak berhubungan, terlihat bahwa baik ODHA yang bekerja maupun yang tidak bekerja sebenarnya sama-sama dapat melakukan tindakan pencegahan penularan HIV dengan baik. Seseorang yang bekerja dan berpenghasilan cukup akan mampu untuk menjangkau kebutuhan yang diinginkan (Siahaan, 2003), termasuk melakukan upaya pencegahan penularan HIV.

\section{Hubungan Lama Menderita HIV/AIDS} dengan Tindakan Pencegahan Penularan HIV. Dalam penelitian ini, proporsi ODHA yang telah lama menderita yang tinggi merupakan kumulatif. Yang harus di waspadai sebenarnya adalah proporsi ODHA baru. Munculnya angka kasus baru ini mungkin tidak representatif, karena bisa saja ODHA tersebut baru teridentifikasi atau berada dalam periode jendela, namun sebenarnya ia sudah terinfeksi HIV. Selama selang waktu belum teridentifikasi, ODHA dapat menularkan HIV dan menyebabkan fenomena gunung es terus terjadi.

\section{Hubungan Status Mendapat ART dengan Tindakan Pencegahan Penularan HIV.} Hasil penelitian memperlihatkan bahwa sebagian besar ODHA sudah mendapat ART. Temuan ini ternyata sejalan dengan laporan Ditjen P2PL bahwa terjadi peningkatan ODHA yang mendapat ART dari tahun 2005 sebanyak 2.381 kasus dan pada Juni 2011 meningkat menjadi 21.775 kasus yang masih menerima ART. Bila dibandingkan dengan total jumlah kasus nasional (26.483 kasus), maka sekitar $82,2 \%$ ODHA telah mendapat ART. Ini berarti telah terjadi suatu lonjakkan angka kasus ODHA yang menjalani ART secara signifikan.

\section{Hubungan Pengetahuan dan Sikap dengan Tindakan Pencegahan Penularan HIV.} Hasil penelitian ini berbeda dengan penelitian Al-Serouri, Anaam, Al-Iryani, Al Deram, dan Ramaroson (2010), yang memperlihatkan bahwa remaja Yaman kurang dalam memiliki informasi tentang HIV/AIDS, hanya $46 \%$ yang 
dapat menyebutkan tiga cara penularan dan hanya $28 \%$ dapat menyebutkan tiga cara untuk menghindari infeksi. Di Ukraina, walaupun 99\% remaja putrinya pernah mendengar tentang AIDS, namun hanya $9 \%$ yang dapat menyebut tiga cara untuk menghindari infeksi HIV (Al-Serouri, Anaam, Al-Iryani, Al Deram, dan Ramaroson, 2010). Tingginya proporsi pengetahuan yang cukup dari ODHA pada penelitian ini dapat dipengaruhi oleh keterpaparan terhadap informasi HIV/AIDS dan frekuensi kunjungan ODHA ke layanan kesehatan.

Hasil penelitian ini berbeda dengan penelitian Campbell (1997, dalam Peltzer, 2000), yang mencatat bahwa orang sub Sahara Afrika memiliki sikap negatif terhadap penggunaan kondom yang dipengaruhi oleh faktor budaya seperti keinginan mendapatkan anak dan pemenuhan seksual perempuan. Sikap positif dan kesadaran akan pentingnya mengetahui status diri terhadap infeksi HIV sangat penting ditumbuhkan di masyarakat guna mencegah dan menekan angka penularan HIV.

\section{Kesimpulan}

Penelitian ini berhasil mengidentifikasi 75 ODHA dengan proporsi antara laki-laki dan perempuannya tidak berbeda signifikan. Sebagian besar responden pada penelitian ini adalah dari kelompok umur muda, tingkat pendidikan rendah dan berstatus kawin dan bekerja. Sebagian besar pengetahuan dan sikap ODHA tentang pencegahan penularan HIV termasuk kategori baik dan berada pada kategori ODHA yang telah lama menderita dan sudah mendapat ART.

Pengetahuan, sikap, jenis kelamin, tingkat pendidikan, status perkawinan, pekerjaan, lama menderita HIV/AIDS dan status mendapat ART tidak berhubungan dengan tindakan pencegahan penularan HIV oleh ODHA di Sorong. Terdapat hubungan antara umur ODHA dengan tindakan pencegahan penularan HIV oleh ODHA. Faktor yang paling meme- ngaruhi tindakan pencegahan penularan HIV oleh ODHA adalah umur $(\mathrm{p}=0,031 ; \alpha=0,05$ $\mathrm{OR}=5,559 \quad 95 \% \quad \mathrm{CI}=1,169-26,423)$. ODHA yang berumur muda berisiko 5,5 kali untuk kurang dalam melakukan tindakan pencegahan penularan HIV dibandingkan dengan ODHA umur tua tanpa dikontrol oleh variabel lain. Berdasarkan hasil penelitian ini menunjukkan umur muda lebih beresiko untuk menularkan HIV dibandingkan umur tua, sehingga hal ini harus menjadi perhatian bagi petugas kesehatan untuk mencegah penularan HIV. Umur muda beresiko menularkan HIV karena cenderung melakukan seks tidak aman. Layanan Asuhan Keperawatan pada ODHA sebaiknya difokuskan pada intervensi konseling cara menghindari seks tidak aman (IDP, DD, TN).

\section{Referensi}

Al-Serouri, Anaam, Al-Iryani, Al Deram, dan Ramaroson. (2010). AIDS awareness and attitude among Yemeni young people living in high-risk area. Eastern Mediterran Health Journal, 16(3), 242-250. Diperoleh dari http://applications.emro.who.int/emhj/V16/03/ 16_3_2010_0242_0250.pdf?ua=1

Dachlia, D. (2000). Faktor-faktor yang berhubungan dengan perilaku seksual berisiko terinfeksi pada pelaut/pekerja pelabuhan di Jakarta, Manado, dan Surabaya (Analisis Data Survei Sirveilans Perilaku 1999) (Tesis, tidak dipublikasikan). Program Studi Ilmu Kesehatan Masyarakat Program Pasca Sarjana Universitas Indonesia, Depok - Jawa Barat, Indonesia.

Dumatubun, A.E. (2003). Pengetahuan, perilaku seksual suku bangsa Marind-Anim. Jurnal Antropologi Papua, 1(3), 32. Diperoleh dari http://papuaweb.org/uncen/dlib/jr/antropologi/

Ignatavicius, D.D., \& Workman, M.L. (2010). Medical surgical-nursing patient-centered collaborative care (6th Ed.). St. Louis, Missouri: Sounders Elsevier.

Irmanigrum, et al., (2007). Situasi perilaku berisiko dan prevalensi HIV di Tanah Papua 2006: Hasil STHP Tahun 2006 di Tanah 
Papua. Jakarta: Badan Pusat Statistik dan Direktur Jenderal PP \& PL DepKes RI

Margono, Y. (2010). Di Kota 175 penderita HIV/AIDS meninggal. Radar Sorong. Diakses 26 Maret 2011, dari http://www.facebook.com /note.php? note_id=277693111871.

Peltzer, K. (2000). Factors Affecting Condom Use Among South African University Students. East African Medical Journal, 77(1), 46-52.

Papua, Elsham. (2010). Penderita HIV/AIDS di Papua Barat 1.589. Cahaya Papua. Diakses 2 Maret 2010, dari http://elshamnewsservice. blogspot.com/2010/04/penderita-hivaids-di-pa pua-barat-1589.html.
P2PL, Ditjen. (2011). Laporan situasi perkembangan HIV\&AIDS di Indonesia sampai dengan Juni 2011. Jakarta: Kementerian Kesehatan RI.

Sastroasmoro, S., Ismael, S. (2010). Dasar-dasar metodologi penelitian Klinis. Jakarta: Sagung Seto.

Stine, G. J. (2011). AIDS update 2011. New York: McGrow-Hill.

UNAIDS. (2009). Annual report 2009. Diakses 28 April 2011, dari http://www.unaids. org/en/me dia/unaids/contentassets/dataimport/pub/report /2010/2009_annual_report_en.pdf. 